\title{
HOW TO APPLY MOLINISM TO THE THEOLOGICAL PROBLEM OF MORAL LUCK
}

\author{
Robert J. Hartman
}

\begin{abstract}
The problem of moral luck is that a general fact about luck and an intuitive moral principle jointly imply the following skeptical conclusion: human beings are morally responsible for at most a tiny fraction of each action. This skeptical conclusion threatens to undermine the claim that human beings deserve their respective eternal reward and punishment. But even if this restriction on moral responsibility is compatible with the doctrine of the final judgment, the quality of one's afterlife within heaven or hell still appears to be lucky. Utilizing recent responses to the problem of moral luck, I explore several Molinist accounts of the final judgment that resolve both theological problems of moral luck. Some of these accounts entirely eliminate moral luck while others ensure that the moral luck involved in the judgment is overall good luck.
\end{abstract}

According to the Christian religion, God judges each human being after his or her death. Some receive rewards and others are punished; each one is treated no worse than what he or she deserves. However, Thomas Nagel argues that a general fact about luck and a plausible moral principle jointly imply the skeptical conclusion that human beings are praiseworthy or blameworthy for at most a tiny fraction of each action. ${ }^{1}$ If human beings are praiseworthy or blameworthy for at most a small fragment of each action, how can each person deserve the reward or punishment that Christian revelation ascribes to him or her? Additionally, even if each person does merit his or her reward or punishment, this restriction on moral responsibility does not eliminate all luck from the final judgment. The quality of one's eternal flourishing or suffering is still subject to luck.

The aim of this essay is to explore several accounts of the final judgment able to resolve both theological problems of moral luck. Each account of the judgment assumes a particular account of moral responsibility and utilizes divine middle knowledge. The first and second accounts adopt a luck-free view of moral responsibility and apply Molinism to develop a moral luck-free version of the judgment. The third account allows our lives to be saturated with moral luck but employs middle knowledge

${ }^{1}$ Thomas Nagel, "Moral Luck," in Mortal Questions, ed. Thomas Nagel (Cambridge: Cambridge University Press, 1979), 24-38. 
to ensure that all moral luck is overall good luck. Given the moral and Molinist assumptions in each account, all three views are logically possible. Nevertheless, each is liable to serious objections. After taking stock of these objections in the final section of the essay, I point in the direction of two additional accounts that avoid many or all of them. The final two accounts eliminate a substantial amount of moral luck and employ Molinism to guarantee that all remaining moral luck is overall good luck.

These Molinist applications may also be relevant to the debate between general theories of divine providence. Thomas Flint suggests that perhaps "the greatest hope for progress" in adjudicating between general theories of divine providence is to consider each of their ramifications for specific Christian doctrines. ${ }^{2}$ According to this criterion, the general view of providence with the most compelling account of difficult Christian doctrines has an edge over the others. The Molinist research program has already covered a lot of ground. Philosophers have, for example, applied Molinism to the problem of evil, original sin, biblical inspiration, papal infallibility, prophecy, unanswered prayers, and the incarnation. ${ }^{3}$ I extend this research program by putting Molinism to work on the final judgment. ${ }^{4}$ If one of these Molinist accounts of the final judgment is not only possible but plausible, it may provide additional motivation for accepting Molinism over competing theories of providence with no comparable application.

\section{The Problem of Moral Luck}

Moral luck occurs when something outside one's control affects that for which one is morally responsible. One kind of moral luck involves the consequences of one's actions. The result of an action is often affected by factors outside of the agent's control. Suppose, for example, that Sally is at a party where she gets drunk and drives home. ${ }^{5}$ On her way home, she swerves and merely hits a curb. However, now suppose that when Sally is

2Thomas P. Flint, "Whence and Wither the Molinist Debate: A Reply to Hasker," in Molinism: The Contemporary Debate, ed. Ken Perszyk (Oxford: Oxford University Press, 2011), 46.

${ }^{3}$ See Alvin Plantinga, The Nature of Necessity (Oxford: Oxford University Press, 1974), chapter 9; Michael Rea, "The Metaphysics of Original Sin," in Persons: Human and Divine, ed. Peter van Inwagen and Dean Zimmerman (Oxford: Oxford University Press, 2007), 319-356; William Lane Craig, " "Men Moved by the Holy Spirit Spoke from God' (2 Peter 1:21): A Middle Knowledge Perspective on Biblical Inspiration," Philosophia Christi 1 (1999), 45-82; Thomas P. Flint, Divine Providence: The Molinist Account (Ithaca, NY: Cornell University Press, 1998), chapters 8-11; Thomas P. Flint “"A Death He Freely Accepted': Molinist Reflections on the Incarnation," Faith and Philosophy 18 (2001), 3-20.

${ }^{4}$ The doctrine of the final judgment has received Molinist treatment before. See Mark B. Anderson, "Molinism, Open Theism, and Soteriological Luck," Religious Studies 47 (2011), 371-381; William Lane Craig, “"No Other Name': A Middle Knowledge Perspective on the Exclusivity of Salvation Through Christ," Faith and Philosophy 6 (1989), 172-188; Linda Zagzebski, "Religious Luck," Faith and Philosophy 11 (1994), 407. I incorporate Zagzebski and Anderson's proposals in the first version of the judgment. In the last four accounts, I adopt and extend Craig's work on soteriology to the theological problem of moral luck.

${ }^{5}$ Nagel, "Moral Luck," 29. 
driving drunk, she not only swerves and hits a curb, but she also kills a pedestrian who just happens to be standing on the curb. The only difference between these outcomes is sheer luck - whether a pedestrian happens to be standing there. Even though Sally's contribution is identical in these scenarios, her blameworthiness differs. In the first scenario, she is not blameworthy for killing someone, and, in the second, she is blameworthy for killing someone. Her blameworthiness is subject to consequential luck.

Another kind of moral luck concerns a person's circumstances. One's actual circumstances fix a particular set of morally significant challenges, which influences the moral quality of what a person freely chooses to do. And because one's actual circumstances are but a small subset of the possible circumstances one could have been in, luck shapes what a person freely does. For example, suppose John is born to a German family near the beginning of the twentieth century, and he is eventually faced with morally significant decisions about whether to join the Nazi regime. ${ }^{6}$ In those circumstances, John freely chooses to become a Nazi and performs actions appropriate to his role. However, if he were to have been presented with a job opportunity in Argentina just prior to the Nazi ascent, he would have freely emigrated and would have freely chosen to become an upstanding Argentinian citizen. ${ }^{7}$ But then, it appears that the circumstances in which John happens to find himself significantly contribute to the kind of actions he performs. His blameworthiness is subject to circumstantial luck.

A final type of moral luck concerns a person's constitution. A person's natural temperament affects the difficulty of making good moral decisions, and one's natural powers (such as the ability to see or hear) significantly affect the kind of moral choices one faces. Suppose Lucy is naturally sympathetic. ${ }^{8}$ Being naturally inclined to care for others in pain, she notices a suffering stranger and stops to help. However, suppose instead that Lucy is naturally cold-hearted or blind. In either case, she would fail to help the stranger, because she would not care about the stranger's well-being or she would fail to perceive the stranger's need. But then, whether Lucy decides to help a suffering stranger substantially depends upon which constitutive properties she happens to have. Her praiseworthiness is subject to constitutive luck.

The next step in the skeptical argument is to introduce an anti-luck moral principle that we may call the diminishing principle or DP: if an action (or its consequences) is significantly affected by factors outside the agent's control, then those factors significantly diminish the agent's praiseworthiness or blameworthiness for that action (or its consequences). ${ }^{9}$ The idea

\footnotetext{
${ }^{6}$ Ibid., 34.
}

${ }^{7}$ Occasionally, I stipulate what a person would freely do in a particular circumstance. Affirming true counterfactuals of creaturely freedom is not required to state the problem of moral luck, but that affirmation does make the problem more acute.

${ }^{8}$ Nagel, "Moral Luck," 32-33.

${ }^{9}$ Nagel states the anti-luck principle in several ways: "people cannot be morally assessed for what is not their fault, or for what is due to factors outside of their control"; "one cannot 
behind the DP is that moral responsibility should be protected from luck. However, applying the DP to each of the above examples produces a skeptical result. Sally's blameworthiness is partially mitigated in the scenario where she kills a pedestrian, because the spatial status of the pedestrian is outside of her control. John, the Nazi, is only partially morally responsible for his actions, because his circumstances are outside of his control and they deeply affect the actions he chooses and forgoes. Sympathetic Lucy is also only partially morally responsible for her actions, because her constitutive properties are outside of her control and they significantly influence her choices.

The above cases plausibly generalize such that all morally significant actions are apparently morally lucky. If we assume that the DP is true, as appears plausible, then moral responsibility for all human actions and their consequences is significantly diminished. To summarize the argument:

(1) All actions and their consequences are significantly affected by factors outside their agent's control.

(2) If an action (or its consequences) is significantly affected by factors outside its agent's control, then those factors significantly diminish the agent's praiseworthiness or blameworthiness for that action (or its consequences).

Therefore,

(3) Every agent's praiseworthiness or blameworthiness is significantly diminished for all actions and their consequences.

How much does luck diminish the agent's praiseworthiness or blameworthiness? Nagel's answer is that "the area of genuine agency, and therefore of legitimate moral judgment, seems to shrink under this scrutiny to an extensionless point."10 This answer also includes the mitigating force of a kind of luck not hitherto mentioned-causal luck. Causal luck occurs when one's actions are causally determined by antecedent states of affairs and the laws of nature. Let us assume that human beings have some version of libertarian free will and are thus not subject to causal luck. That assumption assuages Nagel's extremely skeptical conclusion but plausibly leaves the following moderately skeptical conclusion intact: human beings are praiseworthy or blameworthy for at most a tiny fraction of each action. Call this moderate skeptical conclusion the skeptical conclusion. Given that the above premises are true, the skeptical conclusion appears plausible when one considers how much luck is involved in any choice. Luck influences which non-determining events set the stage for the

be more culpable or estimable for anything than one is for that fraction of it which is under one's control." My formulation more closely resembles the latter. See Nagel, "Moral Luck," $25,28$.

${ }^{10}$ Nagel, "Moral Luck," 35. 
choice as well as what transpires after it. Additionally, luck influences the decision itself through factors internal and external to the agent.

In what follows, I explicate several accounts of the final judgment. Each account assumes a particular response to this skeptical argument. But before I state these responses and integrate them into their respective accounts of the final judgment, I want to consider some implications of the skeptical conclusion for the Christian religion.

\section{The Theological Problem of Moral Luck}

The doctrine of the final judgment states that God judges each person according to his or her pre-mortem actions, ${ }^{11}$ and the verdict is that virtually ${ }^{12}$ all moral agents deserve damnation by their merit alone. However, the claim that human beings are blameworthy for at most a tiny fraction of each action threatens to falsify the claim that each person merits damnation-conceived in a strong or weak sense. The strong version of hell describes damnation as a state where God regularly inflicts pain upon the damned forever. ${ }^{13}$ That view of hell is plausibly undermined, because, if people are morally responsible for only a small part of their earthly lives, it appears plausible that human beings do not merit that degree of retribution. ${ }^{14}$ The weak version of hell describes divine punishment as allowing the wicked person to suffer the natural consequences of his or her vicious character forever ${ }^{15}$ If people are morally responsible for only a small part of their pre-mortem lives, it seems plausible that they do not deserve to suffer the natural consequences of their earthly lives for eternity, because what they do and who they become is deeply influenced by things outside their control.

But suppose that the skeptical problem of moral luck is not a problem. That is, given that human beings are responsible for only a small fraction of their actions, they still merit their respective eternal reward or punishment. Even so, the DP is unable to eliminate all luck from the final judgment, because there is still the comparative problem of moral luck. To illustrate this problem, suppose that blameworthiness is quantifiable in

\footnotetext{
${ }^{11}$ Romans 2:5-6.

${ }^{12}$ I write 'virtually' because all Christian traditions affirm that Jesus is impeccable. Some traditions also claim that Mary is sinless.

${ }^{13}$ See Augustine, The City of God, trans. Marcus Dods (New York: Random House, 1993), 21.9-10; Jonathan Edwards, Sinners in the Hands of an Angry God (Old LandMark Publishing, 2004).

${ }^{14}$ The plausibility of that claim assumes that the following type of argument is unsound: (i) virtually all people sin against God, (ii) a single sin against an infinite being makes the offender infinitely blameworthy, and thus (iii) virtually all people are infinitely blameworthy. For a good discussion of the plausibility of this argument, see Jonathan Kvanvig, The Problem of Hell (Oxford: Oxford University Press, 1993), 27-55.

${ }^{15}$ See C. S. Lewis, The Problem of Pain (New York: HarperCollins Publishers, 1940), chapter 8; Eleonore Stump, "Dante's Hell, Aquinas's Moral Theory, and the Love of God," Canadian Journal of Philosophy 16 (1986), 181-198; Richard Swinburne, "A Theodicy of Heaven and Hell," in The Existence and Nature of God, ed. Alfred J. Freddoso (Notre Dame, IN: Notre Dame Press, 1983), 37-54.
} 
blames. Suppose further that, as a Nazi, John merits 1,000,000 blames but would only deserve 10,000 blames as an Argentinian citizen. If people are morally responsible for only a small part of each action, say $1 / 1000$, then John the Nazi deserves 1,000 blames and John the Argentinian only 10. Even if the fraction for which he is morally responsible is different than $1 / 1000$ or it is a different fraction for different actions, it is still plausible that there is a significant disparity between the moral worth he accrues by acting in different circumstances. The upshot is that even after the DP is applied to his moral worth, there is still some luck in what John is responsible for, which means that his punishment is influenced by luck.

Note that the skeptical and comparative problems are related. As the degree of moral responsibility for each action decreases, the less influence luck has upon one's moral worth but the less plausible the claim that one is blameworthy enough to merit hell. As the degree of moral responsibility for each action increases, the more plausible it is that people merit their punishment but the more influence luck has upon one's moral worth. One way or another, luck poses a difficulty for eternal punishment.

Linda Zagzebski suggests that one way out of these problems is to give up the doctrine of hell. ${ }^{16}$ The idea is to sever the moral from the soteriological order. In that case, God does not punish people at all, and so there are no luck-based problems concerning punishment. The price of this solution is that it departs from the Christian tradition. But let us momentarily assume that this departure is unproblematic in order to see that it may solve only part of each theological problem of moral luck.

While entrance to heaven itself is not a reward for meritorious actions, a prima facie reading of some biblical passages indicates that there is a moral order in heaven. Jesus often asserts that people will have "treasure in heaven" if they sell their possessions and give to the poor. ${ }^{17}$ His followers receive "rewards" in heaven for persevering in faith amidst persecution and are "repaid" at the resurrection for blessing those who lack the means to repay them. ${ }^{18}$ Moreover, his disciples are to "store up ... treasures in heaven" by performing good deeds. ${ }^{19}$ These Scriptures appear to indicate that human beings merit rewards in heaven (but not heaven itself) on account of their earthly deeds.

Both luck-based problems regarding blameworthiness in hell apply mutatis mutandis to meriting rewards in heaven. Given the skeptical conclusion, it seems plausible that people are not praiseworthy enough to merit the rewards the Bible attributes. Furthermore, even if that is not so, the quantity and quality of the meritorious deeds one does perform is still shaped by factors outside one's control. As a result, the rewards one merits in heaven are subject to luck. Assuming the desert interpretation of

\footnotetext{
${ }^{16}$ Zagzebski, "Religious Luck," 410. She does not endorse this view.

${ }^{17}$ Matthew 19:21. All biblical quotations are from the New Revised Standard Version.

${ }^{18}$ Respectively, Luke 6:22-23, 14:13-14.

${ }^{19}$ Matthew 6:20.
} 
heavenly rewards is correct, the entire theological problem of moral luck cannot be solved by abolishing hell, because that solution does not render God's distribution of heavenly rewards moral luck-free. But if someone is already willing to discard the doctrine of hell for a solution to the problem of moral luck, that person is likely also to dispense with the moral order in heaven. This is, however, an additional and unnoticed cost.

Another overlooked ramification of moral luck is that it undermines a popular solution to what we may call the soteriological problem of geographic luck. The problem involves a tension between the claim that a good God would provide everyone with an opportunity to receive his grace, and the claim that some people who are geographically isolated from the Christian message lack opportunity to exercise faith. Some people fail to have access to the cognitive claims of Christianity required for conscious adherence to the Christian religion. One solution to this problem removes some of the cognitive content from faith in order to make exercising faith partially within their control. Though unable to espouse explicit faith, those who are geographically isolated from the Christian message are able to exercise implicit faith. Implicit faith involves seeking God as far as his general revelation permits and following the light of conscience by divine grace. As the Catholic Catechism states,

Those who, through no fault of their own, do not know the Gospel of Christ or his Church, but who nevertheless seek God with a sincere heart, and, moved by grace, try in their actions to do his will as they know it through the dictates of their conscience - those too may achieve eternal salvation. ${ }^{20}$

But whether one follows the dictates of conscience and thus has implicit faith is significantly influenced by luck. Suppose Afram's parents are murdered by a neighboring tribe in an all-too-common tribal war. Left to his lonely circumstances, he freely becomes hard and bitter and cares little about the demands of conscience. He fails to have implicit faith. Suppose instead that Afram's parents had not died at war but lived on to old age. With a family to take care of him, Afram would freely choose to become the kind of person who is sensitive to the dictates of conscience and would come to possess implicit faith. The upshot is that if moral luck exists, then possessing implicit faith seems to be partially a matter of luck. If having implicit faith is itself subject to luck, then it cannot function to remove the luck from God's judgment regarding people who are geographically isolated from the Christian message.

\section{Unrestricted Profile Molinism}

Now that we have a better sense of how luck impacts the doctrines of hell, heaven, and implicit faith, let us consider one way to resolve the skeptical

${ }^{20}$ U.S. Catholic Church, The Catechism of the Catholic Church, 2nd ed. (New York: Doubleday Religion, 2003), section 847. Italics mine. However, non-Catholic philosophers also endorse this idea. See Craig, "No Other Name," 176, 186; Richard Swinburne, Faith and Reason, 2nd ed. (Oxford: Oxford University Press, 2005), 208. 
and comparative problems of moral luck. In this section, I explicate Michael Zimmerman's luck-free account of moral responsibility and then present and critique the resulting account of the final judgment. ${ }^{21}$

Zimmerman's response to the problem of moral luck is to reject the DP for a more general anti-luck principle. ${ }^{22}$ Call this more general principle that "luck is irrelevant to moral responsibility" the irrelevance principle or IP. ${ }^{23}$ The distinctive merit of the IP is that it may entirely eliminate moral luck while avoiding the skeptical conclusion. In what follows, I will apply the IP to each kind of luck in order to show how it avoids the skeptical conclusion; the antiskeptical gain concerns the kinds of luck that most intimately influence what action one performs-circumstantial and constitutive luck.

Zimmerman joins Nagel in thinking that human beings are not morally responsible for the consequences of their actions when they are subject to luck. ${ }^{24}$ The drunk driver in each scenario possesses the same degree of blameworthiness. The unlucky driver is not additionally blameworthy for killing the pedestrian who happens to be standing at the curb. ${ }^{25}$ But agreeing that a person is not morally responsible for the consequences of his or her choice still allows him or her to make a choice. That is not so for circumstantial luck. A small change in an assassin's circumstance may negate his opportunity to decide whether to carry out a hit. ${ }^{26}$ For example, a large truck may suddenly park directly in his line of fire and obstruct his only shot. Or his alarm clock battery may die and he might sleep through his opportunity to shoot the target. Or his girlfriend may regularly call immediately before a lazy mob boss, which prevents him from being hired in the first place.

How is circumstantial luck supposed to be irrelevant to moral responsibility? Zimmerman suggests that it is irrelevant to one's praiseworthiness or blameworthiness which of one's possible circumstances are actual, because people are morally responsible for what they would do in actual and nonactual circumstances. ${ }^{27}$ Supposing that the frequent calls from the assassin's girlfriend result in his failure to be hired, he never forms the intention to kill the mark. Nevertheless, the assassin is still blameworthy for the assassination attempt in virtue of the following true counterfactual: had the mob boss hired him and nothing obstructed his ability to take the shot, the assassin would have formed the relevant intention and taken the shot. Thus, the

${ }^{21}$ Michael J. Zimmerman, "Taking Luck Seriously," The Journal of Philosophy 99 (2002), 553-576.

${ }^{22}$ For his argument against the DP, see his "Luck and Moral Responsibility," Ethics 97 (1987), 376-379.

${ }^{23}$ Zimmerman, "Taking Luck Seriously," 559.

${ }^{24}$ Ibid., 562.

${ }^{25} \mathrm{As}$ Zimmerman notes, there may be non-desert related reasons for treating the drivers asymmetrically. See his "Taking Luck Seriously," 562.

${ }^{26}$ Ibid., 559.

${ }^{27} \mathrm{Ibid} ., 564$. 
assassin is blameworthy even if he is not blameworthy for anything in the actual world.

Zimmerman handles constitutive luck in the same way. ${ }^{28}$ It is irrelevant to one's overall praiseworthiness and blameworthiness which contingent constitutive properties one has in the actual world, because one is morally responsible for the actions one would perform or omit with actual and nonactual contingent constitutive properties. But not all of one's constitutive properties may be contingent. If one's temperament or physical capacities are among one's essential properties, some constitutive luck may not be eliminable. Essential traits are outside of one's control but influence that for which one is morally responsible. The result is that Zimmerman's account of moral responsibility may not be entirely luck-free..$^{29}$

To summarize, the IP implies that the luck that affects one's actions is not moral luck - it does not affect a person's praiseworthiness or blameworthiness. A person is not morally responsible for the consequences of his or her actions that are subject to luck, and one is morally responsible for what one actually does as well as what he or she would do in non-actual circumstances and with non-actual contingent constitutive properties. Assume that Zimmerman's account is correct and combine it with Molinism. In that case, people are praiseworthy and blameworthy for their counterfactual actions in virtue of their morally significant true counterfactuals of creaturely freedom $(\mathrm{CCFs})$. CCFs are propositions of the following form: if free agent $S$ is in complete circumstance $c$, then $S$ would freely (in a libertarian sense) choose $x$. Let us call the set of all true and morally significant CCFs about a person that person's counterfactual moral profile.

This Molinist version of Zimmerman's view of moral responsibility yields an account of the final judgment that is essentially identical with Zagzebski's middle knowledge proposal: God judges each human being for his or her entire counterfactual moral profile-for what each person actually does and for what he or she would do in non-actual circumstances and with non-actual constitutive properties. ${ }^{30}$ Call this view Unrestricted Profile Molinism. Unrestricted Profile Molinism solves both theological problems regarding heaven and hell. Given the IP, the skeptical conclusion is false, because, instead of diminishing what people are responsible for in the actual world, luck implies that people are also morally responsible for what they would do in non-actual circumstances and with non-actual constitutive properties. Furthermore, since people are responsible for their

\footnotetext{
${ }^{28}$ Ibid., 574-575.

${ }^{29} \mathrm{Nicholas}$ Rescher argues that it is incoherent to assert that one has control over his or her constitutive properties, which implies that the scope of anti-luck principles is limited to circumstantial and consequential luck. See his "Moral Luck," in Moral Luck, ed. Daniel Statman (Albany: State University of New York Press, 1993), 155-157. This proposal seems plausible at least regarding essential constitutive properties, because the problem of moral luck is a problem regarding a certain kind of contingency-not necessity. If this is right, Zimmerman's account of moral responsibility is wholly moral luck-free.
}

${ }^{30}$ Zagzebski, "Religious Luck," 407. I should note that she does not endorse this proposal. 
entire counterfactual moral profiles, they are not judged for a small lucky subset of what they would do. The comparative problem of moral luck is thus eliminated.

Additionally, as Mark Anderson argues, this counterfactual account of moral responsibility easily eliminates the problem of soteriological luck. ${ }^{31}$ Suppose that Afram freely fails to have implicit faith in the actual world and that his epistemic and familial circumstances inclined him toward those decisions. Nevertheless, Afram might espouse implicit faith or even explicit faith in some other feasible world. ${ }^{32}$ Since he is morally responsible for what he would do in non-actual circumstances, God may grant Afram eternal beatitude for his response to salvific grace in some other feasible world..$^{33}$

But is it theologically plausible that God judges each person for his or her counterfactual moral profile? There are several reasons to think that one's counterfactual moral profile is not the right object of divine evaluation. One type of problem is that it trivializes the actual world in two ways. First, the majority of entries in one's counterfactual moral profile are not about the actual world. ${ }^{34}$ As a result, one's life in the actual world plays only a negligible role in God's judgment of actual persons. Second, the counterfactual account of moral responsibility makes creation of a premortem existence superfluous to God's moral assessment. ${ }^{35}$ Since people are morally responsible for what they would do in actual and non-actual circumstances, there is no reason why human beings must enjoy premortem lives at all. God may actualize human beings at the final judgment and send them to their eternal destinations.

Others may want to reject Unrestricted Profile Molinism because it is incompatible with the character account of divine reward and punishment. According to the weak version of hell, eternal punishment is living as the vicious person one has chosen to become. However, in different feasible worlds, it is plausible that a person develops different and incompatible character traits. But then punishing a person for his or her counterfactual moral profile turns out to be incoherent; the punishment implies that it is possible for a single person to have incompatible character traits.

A final difficulty is that Unrestricted Profile Molinism is plausibly incompatible with biblical testimony. In Scripture, actual deeds (overt and mental) are exclusively the object of divine evaluation. Consider an

\footnotetext{
${ }^{31}$ Anderson, "Molinism, Open Theism, and Soteriological Luck," 378.

${ }^{32} \mathrm{By}$ 'feasible' world, I mean a possible world that God is able to weakly actualize given all the contingently true CCFs. For a good discussion of feasibility, see Flint's Divine Providence, $46-54$.

${ }^{33}$ As Anderson notes, this view may imply universalism. It depends on whether there are actual persons who would not accept God's invitation to salvation in any feasible world. See his "Molinism, Open Theism, and Soteriological Luck," 378-379.

${ }^{34}$ Anderson, "Molinism, Open Theism, and Soteriological Luck," 379.

${ }^{35}$ Zagzebski, "Religious Luck," 407-408; David P. Hunt, "Middle Knowledge and the Soteriological Problem of Evil," Religious Studies 27 (1991), 18-24.
} 
example: "All of us must appear before the judgment seat of Christ, so that each may receive recompense for what has been done in the body, whether good or evil." ${ }^{36}$ The fact that the Scriptures refer exclusively to actual deeds as the object of divine judgment inductively contributes to the plausibility of the claim that God judges people only for actual deeds. If such Scriptures do make it plausible that God's final judgment ranges over only actual deeds, then Zimmerman's account of moral responsibility is plausibly incompatible with the Christian doctrine of the final judgment.

\section{Restricted Profile Molinism}

There may be a way to integrate Zimmerman's counterfactual view of moral responsibility with an account of the final judgment that avoids these theological difficulties. In this section, I explore such a version of the judgment.

It is agreed by most if not all Christian theologians that gaining salvation requires God's grace. Since whether God bestows salvific grace is outside human control, gaining salvation is subject to luck. However, grace-based luck is different from moral luck. Moral luck is luck regarding what one deserves-one's praiseworthiness or blameworthiness. Divine grace is "religious luck;" it is luck regarding what one receives (not what one deserves) at the final judgment. ${ }^{37}$ Recipients of grace are treated better than they deserve. That God treats people differently than they merit is problematic only when God rewards them less or punishes them more than they deserve. ${ }^{38}$

Here is a coherent way to employ religious luck in restricting the counterfactual acts for which God judges people: people are morally responsible for the actions described in their counterfactual moral profiles, but God graciously judges each human being for a proper subset of his or her counterfactual moral profile - all and only those actions described by the morally significant CCFs with antecedents that obtain in the actual world. Call that proper subset of CCFs an actual moral profile. God judges people for their actual moral profiles where their actual moral profiles are better than their counterfactual moral profiles. As a result, God rewards them more and punishes them less than they merit. His judgment, then, is an expression of grace or religious luck, because people are treated better than they deserve. The world is saturated with religious not moral luck.

What is it for one to have an actual moral profile that is better than his or her counterfactual moral profile? One might think that an actual moral

${ }^{36} 2$ Corinthians 5:10.

${ }^{37}$ Zagzebski, "Religious Luck," 403.

${ }^{38}$ As Zagzebski notes, this is Jesus's lesson in the parable of the laborers in the vineyard (Matthew 20:1-16). See her "Religious Luck," 406. This parable supports the idea that God does nothing wrong by equally rewarding unequal merit; it is not a moral fault to be generous. As Daniel Berntson suggested to me, this may not imply that there is nothing wrong with unequally rewarding equal merit. If he is right, then it is plausible that God rewards those with equal merit in similar fashion. 
profile is better than a counterfactual moral profile if the moral worth of a person's actual moral profile is quantifiably higher than the average moral worth of his or her counterfactual moral profile. However, this suggestion is plausible only if (i) moral worth is quantifiable and (ii) it is possible to average the moral worth of one's counterfactual moral profile. If either of those conditions fail, then perhaps a second proposal, which makes use of an aesthetic analogy, is more adequate. Just as a person with the right sensibilities can pick out an average or typical painting from a particular painter, so God can see which feasible world best exemplifies a person's typical moral worth. Whether a person's average moral worth is discovered by mathematical calculation or something analogous to aesthetic insight, one's actual moral profile is better than one's counterfactual moral profile just in case one has a better moral worth in the actual world than one averages ${ }^{39}$ in the feasible worlds where one exists. ${ }^{40}$

Molinism grants God the resources to securely actualize a world in which each person's actual moral profile is better than his or her averaged counterfactual moral profile. Molinism ascribes middle knowledge to God, knowledge of what any free creature would do in any feasible circumstance. With that knowledge, he can place people in circumstances where they are sure to make free choices that closely align with his purposes. God places the 'saints', those who accept God's offer of salvation, in actual circumstances where they freely choose to become more praiseworthy than is typical for them across feasible worlds. They merit more rewards in virtue of their actual moral profiles than they average by their counterfactual moral profiles. The fact that each redeemed person is rewarded in accordance with his or her actual moral profile is not objectionable, because each is given more than he or she deserves. The damned are also subject to religious luck. ${ }^{41}$ God places damned persons in actual circumstances where they freely choose to become less blameworthy than is typical for them across feasible worlds. The result is that God either inflicts less pain on the damned (on the strong version) or allows them to suffer softer natural consequences (on the weak version). ${ }^{42}$

This Molinist account does not require religious luck-organizing the actual world so that all people have more rewards or less punishments than they average across feasible worlds. God may place people in circumstances where they freely acquire a moral worth in the actual world

\footnotetext{
${ }^{39}$ From now on, I alternate between 'average' and 'typical'; the reader is invited to make the relevant modifications according to his or her preferred account.

${ }^{40} \mathrm{I}$ thank Joel Archer and Mike Mazza for helping clarify this paragraph.

${ }^{41}$ Aquinas agrees. "Even in the damnation of the reprobate mercy is seen, which, though it does not totally remit, yet somewhat alleviates, in punishing short of what is deserved." See his Summa Theologica, trans. Fathers of the English Dominican Province (New York: Benziger Bros, 1948): Ia q.21 a.4 ad.1.

${ }^{42}$ This claim presupposes that there are degrees of punishment in hell. Augustine holds this view in The City of God, 21.16, and it is frequently attributed to Jesus based on Luke 12:47-48 and Matthew 11:21-24.
} 
that is identical to their average counterfactual moral worth. That way, God respectively rewards and punishes the deeds of the saints and the damned exactly in accordance with what they deserve by their average counterfactual moral profiles. However, depending on which CCFs are true, it may not be possible for God to actualize a highly populated world where all people have an identical moral worth in their actual and averaged counterfactual moral profiles. Adding religious luck furnishes God with more creative flexibility, because he need only find a feasible world where the moral worth of each person's actual moral profile is somewhere on a spectrum from slightly higher to vastly higher than his or her average moral worth. Including religious luck in my Molinist account increases its plausibility.

Thus far, we have considered the way moral luck influences a person's placement in a particular level within heaven or hell. Let us now consider the case of how moral luck influences whether a person goes to heaven or hell more generally. Suppose that some soteriological responses in the actual world are subject to circumstantial luck. That is, suppose some people in the actual world who either accept or reject God's offer of salvation would have chosen differently had they been put in different circumstances. That supposition is prima facie plausible, because some circumstances are better than others for inclining a person to accept God's grace and some people would freely choose to make qualitatively different eschatological decisions in different circumstances.

A person's response to God's offer of salvation significantly affects his or her moral profile. The blameworthiness of those who accept God's invitation to salvation is rendered null, and those who reject God's offer of salvation retain their blameworthiness. But then, it follows that whether some people are blameworthy at the final judgment-whether a particular person is rewarded (and not punished) in heaven or is punished (and not rewarded) in hell-is subject to luck. Therefore, if some soteriological responses in the actual world are subject to circumstantial luck, then whether some people are blameworthy at the final judgment is also subject to luck.

The way to show that it is not the case that whether some people are blameworthy at the judgment is lucky is to provide a luck-free account of soteriology. The luck-free soteriology that fits best with my Molinist account is William Lane Craig's Molinist response to the soteriological problem of evil. ${ }^{43}$ The issue he is addressing is the alleged incompatibility between God's existence, goodness, and omnipotence with the fact that some people are eternally damned. Craig's central insight is that, by his middle knowledge, God can arrange circumstances such that all actual persons who would freely accept his invitation to salvation in some feasible world find themselves in actual circumstances where they do freely accept God's grace. However, some people would freely reject God's gift of salvation

${ }^{43}$ Craig, "No Other Name," 179-186. 
in any feasible world; some people have the property of "transworld damnation." 44 Since only the transworldly damned reject God's offer of salvation in the actual world, their soteriological choices in the actual world are not subject to circumstantial luck, because they would not accept God's saving grace in any other feasible world. Put another way, each person's actual soteriological profile is no worse than his or her counterfactual soteriological profile. For some person to have an actual soteriological profile that is no worse than his or her counterfactual soteriological profile is for that person to respond positively to God's grace in the actual world if he or she responds positively to God's grace in any feasible world.

The reason why Craig's luck-free soteriology fits so nicely with my proposal is that my account is an extension of Craig's work. Craig's account explains how one's final destination-heaven or hell-is luck-free. My account extends his work to morality. ${ }^{45}$ It shows how the degree of one's reward or punishment within heaven or hell is not morally lucky. That is, it explains why one's placement within heaven or hell is not shaped by moral but religious luck - or no luck at all if religious luck is omitted.

Call the combination of these Molinist applications Restricted Profile Molinism. Restricted Profile Molinism is the view that God actualizes a feasible world where every person in that world has an actual moral profile better than his or her counterfactual moral profile and an actual soteriological profile no worse than his or her counterfactual soteriological profile. All actual persons have a better moral worth in the actual world than is typical for them across feasible worlds, and all actual persons who would accept God's grace in some feasible world also accept God's invitation to salvation in the actual world. Although each person's actual moral and soteriological profile is subject to luck, it is the benign kind of religious luck. Furthermore, there is a reason to think that God would arrange the world in the way the Restricted Profile Molinist describes. It is

\footnotetext{
${ }^{44}$ According to Craig, actualizing a large number of damned persons might be necessary to actualize a world with a significant number of redeemed persons. The actual world may include an "optimal balance" of saved and damned persons. See his "No Other Name," 184-185. However, this consequentialist reasoning makes the damned a mere means for getting the right number of elect persons, which violates Kant's humanity formulation of the categorical imperative. One way to preserve Craig's claim about necessity without violating the categorical imperative is to adopt a particular account of hell. On this view, God shows the damned kindness in bringing them into existence, because, even for damned souls, it is better for them to exist than never to have existed. As a result, damned persons are not used as a mere means for populating heaven.

Additionally, David Hunt suggests that Craig's claim about the necessity of actualizing damned souls lacks imagination. Since the relational role that damned persons play in the "optimal balance" can be played by mindless simulacra controlled by God's power and middle knowledge, no actual persons need to suffer damnation in order to sufficiently populate heaven. See Hunt's "Middle Knowledge and the Soteriological Problem of Evil," 22-24. Craig retorts that Hunt's suggestion is so "morally abhorrent and unworthy of God that $\mathrm{He}$ could not entertain it." Imagine being married to an automaton or giving birth to one! I find Craig's Cartesian response that God is not a deceiver to be plausible. See Craig's "Middle Knowledge and Christian Exclusivism," Sophia 34 (1995), 133-134.

${ }^{45} \mathrm{Craig}$ would not welcome this particular extension; he explicitly rejects a counterfactual account of moral responsibility in "Middle Knowledge and Christian Exclusivism," 131-132.
} 
good that actual moral profiles are not shaped by moral luck if God judges human beings in the way that the Scriptures indicate.

Restricted Profile Molinism also appears to avoid the theological problems of Unrestricted Profile Molinism. First, one's actual life is not trivial to the final judgment, because one's actions in the actual world are exclusively the object of God's assessment. Furthermore, actual human beings live their pre-mortem lives prior to the judgment; they are not actualized immediately before the judgment itself. Second, the punishments of the damned and the rewards of the saints cannot result in a person possibly possessing incompatible character traits, because each person's life in a single possible world provides the natural consequences for reward or punishment. Third, it is consistent with the plausible reading of Scripture that God's judgment of moral agents is restricted to the actual world.

Restricted Profile Molinism requires one qualification. It does not apply to non-moral agents - human beings who die having never become moral agents in the actual world. ${ }^{46}$ Non-moral agents have no actual moral profile at all, ${ }^{47}$ because they perform no morally appraisable actions. Thus, such human beings cannot have actual moral profiles better than their average counterfactual moral profiles. The upshot is that the explanatory scope of Restricted Profile Molinism is restricted to moral agents; God actualizes a feasible world where every moral agent in that world has an actual moral profile better than his or her counterfactual moral profile and an actual soteriological profile no worse than his or her counterfactual soteriological profile.

What happens to non-moral agents is a thorny issue for any account of the final judgment. While there may be other explanations that shore up this gap, I point toward a possible way to extend the luck-free scope of Restricted Profile Molinism to include non-moral agents (as well as those in the process of becoming moral agents): God judges non-moral agents for their deeds and soteriological responses in some non-actual feasible world where their moral profiles are better than average and their soteriological responses are no worse than they are in any other feasible world. Interestingly, this extension avoids many of the objections to Unrestricted Profile Molinism. First, the triviality objection has no bite, because the actual world is already trivial for the moral lives of non-moral agents. Second, this extension does not result in the problem of possibly acquiring incompatible character traits, because a person is judged for what he or she does in a single possible world. Third, this extension requires that the plausible reading of Scripture (that God judges people for their deeds in the actual world) is restricted to moral agents, which does not appear that implausible.

\footnotetext{
${ }^{46}$ I thank Josh Johnson and James Sterba for pointing this out.

${ }^{47}$ This claim presupposes that human beings do not inherit the blameworthiness of the original parent's fall from grace. For a discussion of pre-Augustinian authorities who hold this view, see Richard Swinburne's Responsibility and Atonement (Oxford: Clarendon Press, 1989), 144-147.
} 
Nevertheless, one theological objection remains. Even if it is compatible with the Restricted Profile Molinist commitment that human beings enjoy pre-mortem existence before God judges them for the restricted set of their CCFs, it is not true that people must enjoy that kind of life before the judgment. This is the case for two reasons. First, people are fundamentally morally responsible for what they would do in any feasible circumstance. Second, CCFs are true independently of any particular possible world being actual. Since being praiseworthy or blameworthy does not require a pre-mortem life, it is possible for God to create and immediately judge human beings. But then, it is possible for God to bypass all pre-mortem and post-mortem evils. ${ }^{48} \mathrm{God}$ is able to judge human beings without their having to experience earthly evil, and he can create and judge only those human beings with a positive response to his offer of salvation in the set of true CCFs for which he holds them accountable. So, while Restricted Profile Molinism fits the data of Scripture and undermines both problems of moral luck, there are serious questions about why God would be motivated to actualize the kind of world specified by the view, because he is able to actualize much better worlds-worlds without pre-mortem and post-mortem suffering.

\section{Morally Lucky Molinism}

There is yet another version of the final judgment that avoids both theological problems of moral luck and is not subject to the motivation problem afflicting both versions of Profile Molinism. This version of the judgment escapes the skeptical argument from moral luck in a way that is antithetical to Zimmerman's approach: it denies categorical anti-luck principles like the DP and IP altogether. ${ }^{49}$ The result is that one's actions and their consequences as well as one's overall moral worth are significantly shaped by moral luck. ${ }^{50}$ Of course, this does not imply that control is irrelevant to responsibility. Assuming that this new response to the problem of moral luck is correct, the skeptical problem of moral luck vanishes. Because luck does not categorically diminish moral responsibility, it is not the case that people are morally responsible for a mere fraction of their actions and their consequences.

But the comparative problem of moral luck is more stubborn. Even if people are morally responsible for their actions and consequences, there is still something unsettling about the fact one might have performed more noble acts and fewer selfish acts had one's circumstances or constitutive properties been different. It is unsettling because it seems unfair that one's luck might be bad luck and thus that one might incur retributive

\footnotetext{
${ }^{48}$ Hunt, "Middle Knowledge and the Soteriological Problem of Evil," 18-19.

${ }^{49}$ Margret Urban Walker holds this view in her "Moral Luck and the Virtues of Impure Agency," Metaphilosophy 22 (1991), 14-27. See also Michael Otsuka's "Moral Luck: Optional, Not Brute," Philosophical Perspectives 23 (2009), 373-388.
}

${ }^{50} \mathrm{By}$ assumption, one's moral worth is not shaped by causal luck. 
punishment from other humans or from God, which might have been avoided but for better luck.

The possibility that one's moral luck is overall bad luck can be eluded by recasting the basic structure of Restricted Profile Molinism with our new assumption. The idea behind Morally Lucky Molinism is that God can providentially ensure that each moral agent's moral worth is shaped by overall good moral luck by managing the constitutive properties each person has, the circumstances each person is in, and the consequences that follow each person's actions. Overall good moral luck involves having a better moral worth (being more praiseworthy and/or less blameworthy) in the actual world than is typical across feasible worlds. In addition to each agent having overall good moral luck, God can guarantee that all moral agents accept God's salvific grace in the actual world if they accept it in any feasible worlds. But then, the unsettling prospect of allowing moral luck in the final judgment is abolished, because the moral luck involved in each person's moral worth is overall good luck.

There are at least four possible ways to extend Morally Lucky Molinism to non-moral agents. ${ }^{51}$ Each possibility assumes that all non-moral agents in the actual world are transworldly damned - they would not freely accept God's invitation to salvation in any feasible world. Some of these possibilities are unorthodox and some require additional assumptions. First, all non-moral agents are sent to heaven at death. It is overall good moral luck for those human beings to die without an actual moral record, because they are not punished in hell as they would have been had God actualized any one of the feasible worlds where they are moral agents. ${ }^{52}$ Second, all non-moral agents are cosigned to limbo at death. Whatever the nature of limbo, it is a better fate than damnation, and so it is good moral luck that non-moral agents die as such. Third, all non-moral agents are damned at death. This possibility requires the following assumption about original sin: each actual human being inherits the blameworthiness of the original parent. ${ }^{53}$ It is good moral luck for such human beings to die as non-moral agents, because they are less blameworthy in the actual world where they do not contribute to their own blameworthiness than they are in other feasible worlds where they are moral agents and do so contribute. Fourth, non-moral agents are annihilated at death. This possibility presupposes that non-moral agents deserve damnation for the original parent's sin and that ceasing to exist is better than experiencing damnation. In that case, it is good moral luck for such human beings

\footnotetext{
${ }^{51}$ Hunt discusses these four possible fates for non-moral agents in his "Middle Knowledge and the Soteriological Problem of Evil," 20.

${ }^{52}$ In some Christian traditions, being baptized is also a source of good moral luck. According to Aquinas, "Christ's merit avails baptized children for the gaining of Happiness, though they have no merits of their own; because by Baptism they are made members of Christ." See Summa Theologica, I-II q.5 a.7 ad.2. I thank Jeremy Skrzypek for this reference.

${ }^{53}$ Augustine holds this view in The City of God, 13.12-14.
} 
to die as non-moral agents, because, as moral agents, they would have sinned and been damned.

\section{A Few Objections}

I have considered objections to several accounts of the judgment along the way but now want to consider some objections that target the heart of the Molinist proposal common to Restricted Profile Molinism and Morally Lucky Molinism. Both views describe God as actualizing a fortunate world. A fortunate world is a world where each actual moral agent develops a moral worth that is better than typical for him or her in other feasible worlds, and each actual moral agent accepts God's invitation to salvation if they accept it in other feasible worlds.

Objection 1: According to the Molinist story, CCFs are contingently true, and their truth-values are such independently of God's will. Molinism thus implies that God is subject to some circumstantial luck. Depending upon which CCFs are true, God may be unable to actualize a fortunate world. The proposition that some fortunate worlds are feasible may be contingently false for all we know. ${ }^{54}$

Reply: One might be tempted to meet this objection by affirming the following moral principle-MP: in virtue of God's goodness, if God actualizes a possible world, he necessarily actualizes a fortunate world. Since God does actualize a world - the actual world - MP implies that some feasible world is a fortunate world. Thus, the proposition some fortunate worlds are feasible is contingently true. Nevertheless, the proponent of Restricted Profile Molinism or Morally Lucky Molinism cannot affirm MP, because jointly affirming MP with either account of the judgment results in absurdities. ${ }^{55} \mathrm{MP}$ states that actualizing a world that is a non-fortunate world is inconsistent with God's goodness. Since God exists and is good in every possible world, any world that is inconsistent with God's goodness is not a genuinely possible world. Thus, MP and perfect being theology imply that non-fortunate worlds are not possible worlds. However, it is also true that each view of the judgment requires that there are non-fortunate feasible (and thus possible) worlds, because if each person's moral worth is better than typical in some feasible worlds, it is also worse than typical in others. The upshot is that either view of the judgment and MP jointly imply that non-fortunate worlds are metaphysically possible and impossible. The lesson is to reject MP.

Consider a more hopeful rejoinder. It is extremely plausible that there must be very sparsely populated fortunate worlds that are also feasible worlds - no matter what CCFs turn out to be true of each person. After all, a fortunate world is merely a better than average world for each of its human inhabitants. Surely any combination of CCFs would yield some feasible and fortunate worlds that enjoy a modest population such as one

\footnotetext{
${ }^{54} \mathrm{I}$ am indebted to David Anderson for this objection.

${ }^{55}$ I thank Thomas Flint for this point.
} 
hundred people-given all the possible persons there are. Is it likewise extremely plausible that there must be at least some highly populated fortunate worlds that are also feasible? The short answer is no. Nevertheless, by making an assumption about the number of possible persons, I find it is epistemically likely God is able to actualize a highly populated fortunate and feasible world. Assume that there is an infinite number of possible persons. Since there is an infinite number of CCFs true about each possible person, I find it plausible that given most combinations of CCFs, there would be some subset of the infinitude of possible persons (like twenty billion) where those persons inhabit a world and each has a better than average moral profile-no matter which CCFs are true. As a result, I find it epistemically likely that the CCFs which are true yield some highly populated fortunate worlds as candidates for actualization if there is an infinite number of possible persons. ${ }^{56}$

Objection 2: Restricted Profile Molinism and Morally Lucky Molinism imply something improbable about some actual persons. These views imply that the worst actual moral agents are better than typical versions of themselves, which implies that the typical moral life for such persons is horrendous. Since it is implausible that these moral agents are consistently horrendous across feasible worlds, these views of the judgment are implausible.

Reply: It is plausible that different people would freely perform divergent actions in the same type of circumstance. As a result, it is plausible that different counterfactual moral profiles contain different true CCFs and that people vary in their average counterfactual moral worth. ${ }^{57}$ Since it is plausible that there are differences among the moral worth of different possible persons, if there are an infinite number of possible persons, I doubt that it is implausible that some of them have horrendous counterfactual moral profiles.

But if it is not implausible that some possible persons have horrendous counterfactual moral profiles, is it implausible that such persons are actual? I contend that there are insufficient grounds to make this claim. It is common enough that a person do not know what he or she would do in circumstances that will obtain in the actual world. However, the vast majority of true CCFs do not have antecedents that obtain in the actual world. The antecedents of most CCFs concern persons in non-actual circumstances and with different constitutive properties. The more dissimilar those circumstances and constitutive properties are from those of the actual world, the less confident one should be about those counterfactual judgments. Since people do not know the truth of many of their CCFs concerning the

\footnotetext{
${ }^{56} \mathrm{As}$ one anonymous referee pointed out, the argument from the infinitude of possible persons has substantive implications for the plausibility of Plantinga's transworld depravity thesis. See Josh Rasmussen's “On Creating Worlds Without Evil-Given Divine Counterfactual Knowledge," Religious Studies 40 (2004).

${ }^{57} \mathrm{John}$ Greco makes a similar claim in "A Second Paradox Concerning Responsibility and Luck," Metaphilosophy 26 (1995), 92-93.
} 
actual world and since people are on worse epistemic grounds regarding most of the CCFs true about them, it is implausible that one has a justified belief about the moral quality of one's counterfactual moral profile as well as those of other persons. Thus, if there are possible persons with horrendous counterfactual moral profiles, no one holds the justified belief that such persons are not actual.

Before I conclude, I want to note some reasons why one might find Restricted Profile Molinism and Morally Lucky Molinism unattractive. Each implies an unpleasant claim about some actual persons. The implication is that the morally worst human beings in the actual world would freely do bad things in most feasible worlds. Undoubtedly, this is a contentious implication. ${ }^{58}$ Furthermore, these views may give rise to unsympathetic or harsh judgments (and treatment) of those who find themselves in statistically corrupting circumstances. ${ }^{59}$ That is, they may provide an occasion for individuals and groups in privileged circumstances to feel or act superior to other individuals and groups in less privileged circumstances. However, neither view of the judgment provides any moral justification for self-righteousness or failing to love one's neighbor. The great commandments still apply.

\section{Concluding Thoughts}

I have argued principally for the following claims. First, given the premises in the skeptical argument, the problem of moral luck threatens to destabilize the doctrines of heaven, hell, and implicit faith. Furthermore, even if the skeptical conclusion does not undermine these doctrines, one's degree of reward or punishment is still subject to luck. Second, there are at least three versions of the final judgment able to resolve both theological problems of moral luck. Each view of the final judgment is conditionally logically possible. The conditions are that Molinism is true and that the relevant view of moral responsibility is correct.

Are any of these accounts also plausible? In my view, there are theological and philosophical objections sufficient to show that none of them are plausible. Restricted and Unrestricted Profile Molinism have a motivation problem. They leave one wondering why God would actualize a world with pre-mortem and/or post-mortem suffering when he is able to actualize a highly populated world without them. Furthermore, Unrestricted Profile Molinism is unable to account for the significance of moral decision making and soteriological responses in the actual world, the character account of divine reward and punishment, and the plausible interpretation of Scripture that divine judgment does not extend beyond the actual world. But unlike Restricted Profile Molinism and Morally Lucky

\footnotetext{
${ }^{58}$ Raymond VanArragon describes Craig's Molinist proposal as "contentious," and, since I adopt and extend Craig's reasoning to morality, the scope of my suggestion is even more contentious. See his "Transworld Damnation and Craig's Contentious Suggestion," Faith and Philosophy 18 (2001).
}

${ }^{59}$ I thank Kathryn Pogin and Dustin Crummett for this point. 
Molinism, Unrestricted Profile Molinism is not subject to the unpleasant implication regarding the typical badness of actually bad persons.

There are also serious philosophical objections to the views of moral responsibility presupposed in all three Molinist accounts. As Brynmor Browne puts it, anti-luck moral principles appear "impossible to deny ... and impossible to sustain." ${ }^{60}$ The IP protects moral responsibility from luck by opening its scope to other possible worlds. But that comes at the following counterintuitive cost: one might be blameworthy for genocide or praiseworthy for curing cancer when one has brought about neither of those states of affairs in the actual world. This is a significant revision of common sense morality even if epistemic limitations would preclude human beings from rewarding and punishing others for their counterfactual acts and even if divine grace limits rewards and punishment to one's actions in the actual world.

Furthermore, denying categorical anti-luck principles (like DP and IP) and admitting that our lives are permeated with moral luck has its own counterintuitive costs. When Bernard Williams introduced the term 'moral luck' into the literature, he expected it to "suggest an oxymoron." 61 The sphere of morality is supposed to be fair-ultimately just. But the existence of moral luck renders morality unfair, because the sphere of what people are responsible for outstrips what they have control over. One may be justly punished by human beings and ultimately by God for actions (and their consequences) that are significantly shaped by luck. A cost about the nature of morality remains even if Morally Lucky Molinism mitigates some of its force by eliminating overall moral tragedy.

However, there may be other accounts of the judgment in the same neighborhood that are not subject to these objections, because they take an intermediate path between affirming the IP and accepting moral luck wholesale. Such views embrace less extreme anti-luck principles that are not subject to the same problems as the IP. But since these principles do not entirely eliminate moral luck, the familiar Molinist proposal may be recast to ensure that the remaining moral luck is overall good luck. I conclude by briefly sketching two such views.

The first account affirms a suitably qualified version of the DP and thus mitigates most of each kind of moral luck. The result would be that human beings are praiseworthy or blameworthy for at most a tiny fraction of each action. ${ }^{62}$ Suppose this skeptical conclusion is compatible with the scriptural account of the judgment. Because the DP does not entirely eliminate any kind of moral luck, we may apply the familiar Molinist proposal. Even though each moral agent's actions and character are mostly aesthetic, one's

\footnotetext{
${ }^{60}$ Brynmor Browne, "A Solution to the Problem of Moral Luck," Philosophical Quarterly 42 (1992), 345.

${ }^{61}$ Bernard Williams, "Postscript," in Moral Luck, ed. Daniel Statman (Albany: State University of New York Press, 1993), 251.

${ }^{62}$ According to Zagzebski, there may not be a part of an action that is under the control of the agent. See her "Religious Luck," 408.
} 
moral worth, which includes the moral quality of the tiny fraction of each action for which one is morally responsible, turns out to be better than is typical for each person in other feasible worlds. Furthermore, each moral agent freely accepts God's grace in the actual world if they freely accept it in other feasible worlds. This view obviously avoids the theological and philosophical problems associated with the counterfactual accounts of the judgment and also assuages the unsettling prospect of allowing moral luck in the final judgment.

The second account wholly eliminates most but not all forms of moral luck by endorsing a new version of the irrelevance principle-IP*: consequential and circumstantial luck are irrelevant to moral responsibility. One is not responsible for the consequences of one's actions that are subject to luck, and one is morally responsible for the actions he or she performs or omits in the actual world as well as what he or she would freely do in non-actual circumstances with the character one has in the actual world. ${ }^{63}$ Since factors outside one's control influence the actual character one acquires, this view allows for the existence of constitutive moral luck. ${ }^{64}$ But God can actualize a world where each person enjoys overall good constitutive luck. Each moral agent in the actual world finds him or herself with contingent constitutive properties and in circumstances where he or she performs and omits actions that develop a character (and thus a set of true CCFs for which one is responsible) that is better than is typical for him or her in other feasible worlds. Additionally, for any actual moral agent who freely receives God's salvific grace in some feasible world, that agent also does so in the actual world or in some relevant feasible world.

This moderate counterfactual view of moral responsibility avoids most of the problems with both versions of Profile Molinism. The development of character in the actual world requires pre-mortem existence and is necessary to be responsible for any CCFs, which avoids the motivation and triviality problems. And since it is unlikely that one is responsible for actions wildly outside of one's actual moral character or beyond one's actual intellectual ability, it attenuates the counterintuitive implications to Zimmerman's IP. Additionally, it is compatible with the character view of divine reward or punishment. However, it does not fit with the plausible interpretation of Scripture that divine assessment of moral agents is limited to the actual world.

\footnotetext{
${ }^{63}$ Scott Davidson has also recommended a moderate counterfactual view. According to him, CCFs with antecedents "that might easily have obtained" in the actual world are relevant to moral assessment but not those which are improbable. His very brief suggestion is different from the view I suggest here. See his "Salvific Luck," International Journal for Philosophy of Religion 45 (1999), 133.

${ }^{64} \mathrm{Greco}$ suggests that restrictions on personal identity rule out the application of antiluck principles to constitutive luck. See his "A Second Paradox Concerning Responsibility and Luck," 94-95; "Virtue, Luck, and Pyrrhonian Problematic," Philosophical Studies 130 (2006), 26.
} 
These Molinist applications may also have implications for the debate about general theories of divine providence. I have not argued that any of these accounts of the judgment are plausible. However, if any of them (or others like them) are plausible and if other general theories of divine providence have no comparable application regarding these theological problems of moral luck, then Molinism may have a small advantage over them..$^{65}$

St. Louis University

${ }^{65} \mathrm{I}$ am grateful for comments on some version of this paper from Joel Archer, Daniel Berntson, Thomas Flint, John Greco, Ben Hart, Gideon Jeffrey, Josh Johnson, Josh Rasmussen, Michael Rea, Noël Saenz, and several anonymous referees at Faith and Philosophy. I am also thankful for questions and comments from the participants at the Master Class on Divine Foreknowledge and Human Freedom in Munich and at Notre Dame's Center for Philosophy of Religion reading group. 